\title{
Serological screening and toxoplasmosis exposure factors among pregnant women in South of Brazil
}

\author{
Triagem sorológica e fatores de risco para toxoplasmose \\ em gestantes no Sul do Brasil
}

\author{
Silvia Maria Spalding ${ }^{1,2}$, Maria Regina Reis Amendoeira ${ }^{3}$, Carlos Henrique Klein ${ }^{4}$ \\ and Luis Carlos Ribeiro 5
}

\begin{abstract}
Serological screening and evaluation of exposure factors for Toxoplasma gondii transmission were conducted in 2126 pregnant women from southern Brazil. Specific antibodies against Toxoplasma gondii were presented by $74.5 \%$ ( $n=1583$ ) of the pregnant women evaluated. Contact with soil was found to be the major factor for infection.
\end{abstract}

Key-words: Congenital toxoplasmosis. Exposure factor. Pregnant women. Epidemiology. South Brazil.

\section{RESUM0}

Screening sorológico e avaliação de fatores de risco para a transmissão de Toxoplasma gondii foi conduzido em 2.126 gestantes no sul do Brasil. Entre as gestantes avaliadas, 74,5\% ( $n=1.583)$ mostraram anticorpos específicos contra Toxoplasma gondii. 0 contato com o solo foi o maior fator associado à infecção.

Palavras-chaves: Toxoplasmose congênita. Fatores de exposição. Gestante. Epidemiologia. Sul do Brasil.

Toxoplasmosis has a wide geographical distribution. It is a serious health problem in various countries and its diagnosis is crucial for pregnancy assistance programs. It is caused by Toxoplasma gondii an obligate intracellular coccidian that can parasitize either humans or a wide range of other vertebrate species.

There are several well-known means of transmission. These include eating raw meat or poorly cooked meat containing bradyzoites, and the ingestion of oocysts from cat feces in soil, water or food. Infection transmission depends on the level and the frequency of exposure to such factors ${ }^{217}$. Congenital transmission occurs when a woman acquires the infection for the first time during pregnancy and transmits it to her fetus ${ }^{15} 2231$. According to Wong and Remington $\mathrm{n}^{49}, 90 \%$ of these cases are asymptomatic or oligosymptomatic. The frequency of toxoplasmosis acquisition during pregnancy ranges from 1 to 4 per 1,000 pregnancies in several countries, and congenital infection has a prevalence of 0.2 to 2 per 1,000 births $^{48}$.
It is estimated that 20 to $90 \%$ of the world adult population, depending on the region, already have had contact with the parasite $^{18}$. Nevertheless, initial infection and subsequent chronic infection are usually benign in immunocompetent subjects. This zoonosis can be found on all of the continents and under different climatic conditions ${ }^{33942}$. Seropositivity is higher in hotand humid areas $^{13}{ }^{14}{ }^{47}$. Toxoplasmosis prevalence is related to several factors, including cultural level, nutritional habits, age, and rural or urban setting ${ }^{12332}$. Frequency of infection increases with older age groups $s^{2533} 384$, since the probability of an individual coming into contact with one of the transmission routes increases as his or her age increases ${ }^{335}$. Several authors have emphasized the influence of urban versus rural settings in toxoplasmosis. The presence of cats is relevant, since this animal has a well documented role in the T. gondii life cycle ${ }^{3101121}$.

An important mechanism of transmission is the ingestion of raw or poorly cooked contaminated meat ${ }^{542}$. In addition,

\footnotetext{
1. Laboratório de Parasitologia do Instituto de Pesquisas Biológicas do Laboratório Central do Estado da Fundação Estadual de Produção e Pesquisa em Saúde da Secretaria da Saúde do Estado do Rio Grande do Sul, Porto Alegre, RS. 2. Faculdade de Farmácia da Universidade Federal do Rio Grande do Sul, Porto Alegre, RS. 3. Departamento de Protozoologia do Instituto Oswaldo Cruz da Fundação Oswaldo Cruz, Rio de Janeiro, RJ. 4. Departamento de Epidemiologia e Métodos Quantitativos em Saúde da Escola Nacional de Saúde Pública da Fundação Oswaldo Cruz, Rio de Janeiro, RJ. 5. Hospital da Criança Santo Antônio, Porto Alegre, RS, Brasil. Endereço para correspondência: Drạ Sílvia Maria Spalding. Faculdade de Farmácia/UFRGS. Av. Ipiranga 2753, 90610-000 Porto Alegre, RS.

Fax: 55 51-3339-3653

e-mail: spalding@ farmacia.ufrgs.br

Recebido para publicação em 15/07/03

Aceito em 16/11/2004
} 
infection of hunters and butchers occurs with bradyzoite stages during meat processing ${ }^{24}$. Even though there are few cysts in meat, high meat consumption augments the risk of infection ${ }^{17}$. The ingestion of home-made sausage, a tradition introduced by European immigrants ${ }^{23}$, is probably responsible for the high prevalence of toxoplasmosis in certain regions. People that consume high amounts of meat and raw or poorly cooked meat products and who live in regions with poor sanitation have the highest rates of infection.

Oocyst-contaminated vegetables and water are also an important mechanism of transmission ${ }^{29}$. This means of infection is possibly responsible for infection by $\mathrm{T}$. gondii in vegetarians and herbivores ${ }^{36}$.

Italian, German, Polish, and Portuguese immigrants colonized the northeastern region of the state of Rio Grande do Sul. Their descendants have an economy related to swine production. This region has the world's highest rate of ocular toxoplasmosis, known as acquired toxoplasmic retinochoroiditis, with 17.7\% prevalence in the rural population of Erechim ${ }^{43} 44$.

The absence seroprevalence data on pregnant women from this region and the high prevalence of ocular problems motivated this work. Our objective was to determine the primary incidence of toxoplasmosis among pregnant women and the correlated exposure factors ${ }^{46}$.

\section{MATERIAL AND METHODS}

Population. The study population comprised pregnant women from 29 municipalities in the State of Rio Grande do Sul. They were being attended by the Brazilian Public Health System. This area, denominated the 11th Health Region Coordination, is located in Alto Uruguai, part of the northwest region of the state, in southern Brazil (approximately $27^{\circ} \mathrm{S}$ latitude and $52^{\circ} \mathrm{W}$ longitude) at an altitude of $768 \mathrm{~m}$, with an area of $6,279.4 \mathrm{~km}^{2}$, which represents $2.2 \%$ of the total area of the state. This region comprises 31 municipalities, with 233,502 inhabitants, 58.7\% in urban areas and $42.3 \%$ in rural areas, representing $2.4 \%$ of the state's population.

Sample collection and serological studies. From July 15, 1997 to December 31, 1998, 2,126 pregnant women were evaluated in the age range of 12 to 48 years old. They were checked for immunoglobulin types IgG, through indirect immunofluorescence (IIF) with Salck tachyzoites, and IgM through enzyme linked immunosorbent assay (ELISA) of the Trinity Biotech developed at Central Laboratory of the State Secretary of Health. Negative and positive controls had the three tests with agreement. IgM positive subjects were tested for rheumatoid factor with Wiener Kit.

Epidemiology. During the first medical consultation with pregnant women we completed an exposure factor questionnaire. The exposure factors considered for T. gondii were as follows: rural versus urban location; use of untreated water from waterholes, wells or springs; absence of public refuse collection; direct contact with soil; contact with animals ( such as cats, dogs, swine and cattle which may have oocysts on their hair); rodents in the home or surroundings; intake of poorly cooked meat, homemade sausage and craft food products (for the purposes of this paper craft food products refers to sausage or other meat products prepared domestically); and intake of raw milk. Such factors were evaluated both in groups and individually.

The infected group was considered to be pregnant women who presented anti-T. gondii specific antibodies ( IgG) at any time during pregnancy.

Statistical analysis. Prevalence ratio was used to measure the intensity of association with exposure factors in the presence of specific antibodies ( $\operatorname{IgG}$ )-T.gondii. Methods of linear regression were used for adjusted prevalence of infection ${ }^{28}$, presented separately according to housing location (urban or rural). Confidence limits were not estimated for the statistics obtained, since all women in the targetpopulation were examined and thus the method was not susceptible to sampling errors.

\section{RESULTS}

Among the pregnant women, $74.5 \%(\mathrm{n}=1583)$ presented specific antibodies to $\mathrm{T}$. gondii, of which, $3.6 \%(\mathrm{n}=77)$ were IgM reagent. Seropositivity rates increased significantly with age, from 55.6 to $100 \%$. The mean age of women with antibodies was 26.2 years. The mean age of seronegative women was 24.8 years.

In $25.1 \%(n=513)$ of the studied women, specific antibodies were not identified. Among those who exhibited antibodies against T. gondii, $91.4 \%(\mathrm{n}=52)$ had titers equal to or less than 1:1,024. Among women with IgG reagent and IgM non-reagent antibodies, $92.6 \%(\mathrm{n}=1395)$ showed titers equal to or less than 1:1,024, while in IgG and IgM reagent women, only $67.6 \%(n=52)$ showed the same titers. The highest antibody titer observed was 1:32,000.

All of the studied exposure factors contribute to toxoplasmosis transmission with ratio of prevalence $(\mathrm{RP})$ ranging from 1.05 to 1.20 when considered alone, and from 1.31 to 1.73 when considered altogether. Adjusting by regression, it was observed that the group of pregnant women who lived in urban areas, and had contact with soil, and keptcats, and/or had rodents in their houses, and who ate raw or poorly cooked meat and homemade sausage showed an adjusted prevalence ( $\mathrm{P} *$ ) of 83.4\%. Those who lived in rural areas, with the same exposure factors as above showed P* of $81.9 \%$. However, the increase of annual prevalence was higher in the rural area $(b=0.6 \%$ per year of age) than in urban area ( $b=0.4 \%$ for year of age).

Therefore, the difference between adjusted prevalence of these two groups decreases as the age of the women decreases, such that the prevalence is practically the same at 40 years old ( $\mathrm{P}^{*}=89.3 \%$ in urban areas and $\mathrm{P}^{*}=89.1 \%$ in rural areas) (Tables 1 and 2).

In urban areas, the following factors influenced toxoplasmosis prevalence in a decreasing order of significance: contact with soil 
Table 1 - Adjusted prevalence* ( $\left.P^{*}\right)$ of IgG reagent pregnant women from urban area, according to the presence of exposure factors, in women at the mean age ( 25 years old) and women in specific age groups, attended at SUS, 11th Health Region Coordination of the State of Rio Grande do Sul (1997-1998)

\begin{tabular}{|c|c|c|c|c|}
\hline Factors & $\begin{array}{l}\text { Average } \\
\mathrm{P}^{*}(\%)\end{array}$ & $\begin{array}{c}\text { P* } 20 \text { years } \\
(\%)\end{array}$ & $\begin{array}{c}\text { P* } 30 \text { years } \\
(\%)\end{array}$ & $\begin{array}{c}\text { P* } 40 \text { years } \\
(\%)\end{array}$ \\
\hline Soil meat homemade sausage cat rodent & 83.4 & 81.2 & 85.3 & 89.3 \\
\hline Soil meat homemade sausage rodent & 78.3 & 76.1 & 80.2 & 84.3 \\
\hline Soil meat homemade sausage cat & 80.8 & 78.6 & 82.7 & 86.8 \\
\hline Soil meat cat rodent & 80.3 & 78.1 & 82.2 & 86.3 \\
\hline Soil homemade sausage cat rodent & 79.1 & 76.9 & 81.0 & 85.1 \\
\hline Meat homemade sausage cat rodent & 74.3 & 72.1 & 76.2 & 80.3 \\
\hline Soil meat homemade sausage & 75.7 & 73.5 & 77.6 & 81.7 \\
\hline Soil meat cat & 77.7 & 75.5 & 79.6 & 83.7 \\
\hline Soil homemade sausage cat & 76.5 & 74.3 & 78.4 & 82.5 \\
\hline Soil meat rodent & 75.2 & 73.0 & 77.1 & 81.2 \\
\hline Soil homemade sausage rodent & 74.0 & 71.8 & 75.9 & 80.0 \\
\hline Soil cat rodent & 76.0 & 73.8 & 77.9 & 82.0 \\
\hline Meat homemade sausage cat & 71.7 & 69.5 & 73.6 & 77.7 \\
\hline Meat cat rodent & 71.2 & 69.0 & 73.1 & 77.2 \\
\hline Homemade sausage cat rodent & 70.0 & 67.8 & 71.9 & 76.0 \\
\hline Soil homemade sausage & 71.4 & 69.2 & 73.3 & 77.4 \\
\hline Homemade sausage rodent & 64.9 & 62.7 & 66.8 & 70.9 \\
\hline Soil meat & 72.5 & 70.3 & 74.4 & 78.5 \\
\hline Cat rodent & 66.8 & 64.6 & 68.7 & 72.8 \\
\hline Soil cat & 73.3 & 71.1 & 75.2 & 79.3 \\
\hline Soil rodent & 72.8 & 70.6 & 74.7 & 78.8 \\
\hline Homemade sausage cat & 67.4 & 65.2 & 69.3 & 73.4 \\
\hline Meat rodent & 66.0 & 63.8 & 67.9 & 72.0 \\
\hline Meat cat & 68.5 & 66.3 & 70.4 & 74.5 \\
\hline Meat homemade sausage & 66.6 & 64.4 & 68.5 & 72.6 \\
\hline Homemade sausage & 62.3 & 60.1 & 64.2 & 68.3 \\
\hline Cat & 64.2 & 62.0 & 66.1 & 70.2 \\
\hline Rodent & 61.7 & 59.5 & 63.6 & 67.7 \\
\hline Meat & 63.4 & 61.2 & 65.3 & 69.4 \\
\hline Soil & 68.2 & 66.0 & 70.1 & 74.2 \\
\hline № exposure & 59.1 & 56.9 & 61.0 & 65.1 \\
\hline
\end{tabular}

*by linear regression. $\mathrm{P} *(\mathrm{IgG})=48.8+(2.6)$. (X rodent) $+(5.1) .(\mathrm{X}$ cat $)+$ (9.1). (X soil) $+(4.3) \cdot($ X meat $)+(3.2) \cdot(X$ tinned $)+(0.41) \cdot($ age $)$

Present rodent $X=1$; absent rodent $X=0$; present cat $X=1$; absent cat $X=0$; contact with soil $X=1$; no contact with soil $X=0$; intake of poorly cooked meat $X=1$; no intake of poorly cooked meat $X=0$; with intake of craft tinned products $X=1$; without intake of craft tinned products $X=0$

$(b=9.1 \%)$; contact with cats $(b=5.1 \%)$; intake of poorly cooked meat $(b=4.3 \%)$; intake of homemade sausage $(b=3.2 \%)$; and houses with rodents $(b=2.6 \%)$. In rural areas the following order of influence was observed: contact with soil $(b=6.8 \%)$; intake of poorly cooked meat $(b=3.6 \%)$; contact with rodents $(b=2.4 \%)$; intake of homemade sausage $(b=1.6 \%)$; and contact with cats $(b=1.3 \%)$.

In the group with IgM reagent antibodies $(\mathrm{n}=77)$, the statistically significant risk factors were: contact with animals and soil $(\mathrm{n}=63)$; and intake of homemade sausage $(\mathrm{n}=64)$.

\section{DISCUSSION}

In the present study, a higher prevalence ( $74.5 \%)$ than those published for other parts of Latin America (50 to 60\%) was
Table 2 - Adjusted prevalence* (P*) of IgG reagent pregnant women from rural area, according to the presence of exposure factors, in women at the mean age (27 years old) and women in specific age groups, attended at SUS, 11th Health Region Coordination of the State of Rio Grande do Sul (1997-1998).

\begin{tabular}{|c|c|c|c|c|}
\hline Factors & $\begin{array}{l}\text { Average } \\
\mathrm{P}^{*}(\%)\end{array}$ & $\begin{array}{c}\text { P* } 20 \text { years } \\
(\%)\end{array}$ & $\begin{array}{c}\text { P* } 30 \text { years } \\
(\%)\end{array}$ & $\begin{array}{c}\text { P* } 40 \text { years } \\
(\%)\end{array}$ \\
\hline Soil meat homemade sausage cat Rodent & 81.9 & 78.0 & 83.5 & 89.1 \\
\hline Soil meat homemade sausage Rodent & 83.2 & 79.3 & 84.8 & 90.3 \\
\hline Soil meat homemade sausage cat & 79.5 & 75.6 & 81.1 & 86.6 \\
\hline Soil meat cat rodent & 80.4 & 76.5 & 82.0 & 87.5 \\
\hline Soil homemade sausage cat rodent & 78.4 & 74.5 & 80.0 & 85.5 \\
\hline Meat homemade sausage cat rodent & 75.1 & 71.2 & 76.7 & 82.2 \\
\hline Soil meat homemade sausage & 80.8 & 76.9 & 82.4 & 87.9 \\
\hline Soil meat cat & 78.0 & 74.1 & 79.6 & 85.1 \\
\hline Soil homemade sausage cat & 76.0 & 72.1 & 77.6 & 83.1 \\
\hline Soil meat rodent & 81.7 & 77.8 & 83.3 & 88.8 \\
\hline Soil homemade sausage rodent & 79.6 & 75.7 & 81.2 & 86.7 \\
\hline Soil cat rodent & 76.8 & 72.9 & 78.4 & 83.9 \\
\hline Meat homemade sausage cat & 72.7 & 68.8 & 74.3 & 79.8 \\
\hline Meat cat rodent & 73.5 & 69.6 & 75.1 & 80.6 \\
\hline Homemade sausage cat rodent & 71.5 & 67.6 & 73.1 & 78.6 \\
\hline Soil homemade sausage & 77.3 & 73.4 & 78.9 & 84.4 \\
\hline Homemade sausage rodent & 72.8 & 68.9 & 74.4 & 79.9 \\
\hline Soil meat & 79.3 & 75.4 & 80.9 & 86.4 \\
\hline Cat rodent & 69.9 & 66.0 & 71.5 & 77.0 \\
\hline Soil cat & 74.4 & 70.5 & 76.0 & 81.5 \\
\hline Soil rodent & 78.1 & 74.2 & 79.7 & 85.2 \\
\hline Homemade sausage cat & 69.1 & 65.2 & 70.7 & 76.2 \\
\hline Meat rodent & 74.8 & 70.9 & 76.4 & 81.9 \\
\hline Meat cat & 71.1 & 67.2 & 72.7 & 78.2 \\
\hline Meat homemade sausage & 74.0 & 70.1 & 75.6 & 81.1 \\
\hline Homemade sausage & 70.4 & 66.5 & 72.0 & 77.5 \\
\hline Cat & 67.6 & 63.7 & 69.2 & 74.7 \\
\hline Rodent & 71.2 & 67.3 & 72.8 & 78.3 \\
\hline Meat & 72.4 & 68.5 & 74.0 & 79.5 \\
\hline Soil & 75.7 & 71.8 & 77.3 & 82.8 \\
\hline № exposure & 68.9 & 65.0 & 70.5 & 76.0 \\
\hline
\end{tabular}

* by linear regression

$\mathrm{P}^{*}(\mathrm{IgG})=54.0+(2.4) .(\mathrm{X}$ rodent $)+(-1.3) .(\mathrm{X}$ cat $)+(6.8) .(\mathrm{X}$ soil $)+(3.6) .(\mathrm{X}$ meat $)+$ (1.6). (X tinned) $+(0.55)$. (age)

Present rodent $X=1$; absent rodent $X=0$; present cat $X=1$; absent cat $X=0$; contact with soil $X=1$; no contact with soil $X=0$; intake of poorly cooked meat $X=1$; no intake of poorly cooked meat $X=0$; with intake of craft tinned products $X=1$; without intake of craft tinned products $X=0$

observed for people between 20 and 30 years old ${ }^{16}$. However our analysis shows similar mean values of prevalence (78.8\%) to those observed among pregnant women in Rio de Janeiro9.

Studies conducted with pregnant women on other continents have reported varying prevalence: 9.8\% in Hong Kong; 28\% in Denmark; 49\% in Algeria; and 83\% in France ${ }^{27} 30$.

In our study, considering housing location, $78 \%$ of the pregnant women from rural areas were seropositive against $71.3 \%$ from urban areas. This shows a relevant difference of prevalence in these locations. These data support other authors who have reported a higher prevalence of these zoonoses in rural areas $^{19} 35374245$. This is probably due to the higher exposure of rural population in an environment contaminated by 0ocysts ${ }^{46}$.

In this study we observed that the prevalence of infection increases with older age groups. This is due to the cumulative 
probability of a woman having contact with one of the several routes of infection as she ages ${ }^{35}$. High values of prevalence for infection by $\mathrm{T}$. gondii were found in young adult women, probably due to more frequent toxoplasma contact in childhood and adolescence. It is important to consider that the population in this study belongs to the middle or lower classes and is made up of a high number of women that work in activities that bring them in contact with soil. They often work on small family farms and have had intense contact with soil oocysts since childhood. Thus it is probable that pregnant women in rural areas have more contact with sources of infection.

Among the studied women, 25.5\% ( $\mathrm{n}=513)$ did not present specific antibodies against T. gondii, consequently they are at high-risk for first infection during pregnancy. This is consistent with studies in other countries. Cuba, for example, has 29.1\% seronegativity in pregnant women ${ }^{20}$. However such data differ between authors, in Nigeria, women of reproductive age show $54.3 \%$ seronegativity ${ }^{34}$. The existence of this group of women susceptible to first infection during pregnancy and possible congenital transmission indicates the need for primary, secondary and tertiary prevention.

All of the exposure factors studied in this research, when analyzed separately, showed prevalence ratios ranging from 1.05 to 1.20 , except for presence of cats in a rural area. We were not able to obtain a prevalence ratio value for cats in rural areas with this data set ${ }^{46}$. Soil was the variable with the strongest association with infection by $\mathrm{T}$. gondii $(\mathrm{RP}=1.20)$, probably because it is a direct source of oocysts. Contact with soil is the most frequent variable among pregnant women, even among those from urban areas, (82.5\% reported contact with soil). The vast majority of pregnant women had contact with animals (78.8\%). This may also have contributed to the high frequency of infection in the Alto Uruguay region.

Concerning the nutritional habits of the studied population, intake of homemade sausage (78\%), raw milk consumption (68.6\%) and intake of poorly cooked meat (23.9\%) were very common. All these variables showed a prevalence ratio higher than 1. This leads us to believe that such factors are also involved in T. gondii transmission in that region. It is noteworthy that even when pregnant women did not report intake of poorly cooked meat and homemade sausage, many of them, reported that they produced sausages at home. They reported handling the sausage meat and sometimes tasting it before the sausage was cooked. This fact corroborates the work of Jamra ${ }^{25}$, that housewives were infected when preparing meals in São Paulo.

The tachyzoite stage of the parasite is involved with the intake of raw milk ( $R P=1.11$ ), and could have importance as a source of infection. Human infection through breast feeding ${ }^{7}$ and nonprocessed goat milk $\mathrm{k}^{41}$ is reported, and other authors also state that milk from several animals is a potential source of T. gondii transmission.

When analyzing groups of exposure factors, we observed that the prevalence ratio rose to 1.31 and became higher (1.73) when contact with animals and poorly cooked meat were included. By statistical modeling, it was observed that in the study population, contact with cats had a higher influence as an exposure factor in urban areas, which was responsible for a proportion of etiologic impact of $5.1 \%$. This is probably due to the close contact of pregnant women with these animals. In the rural region, cats do not have such close contact with pregnant women, and therefore are a less significant source of environmental contamination. The epidemiological importance of cats is noteworthy since they are the only source of oocysts for environment contamination.

In the group with IgM reagent antibodies, with more recent infection, the risk factors confirm that contact with animals, soil and alimentary ingestion of homemade sausage have an important influence on infection by T. gondii.

We found a lower increase in the proportion, and even a decrease in the proportion, of infection, according to seroprevalence observed in rural areas. This is probably due to cat defecation in peripheral areas not usually frequented by humans. Several authors noticed the high prevalence of seroreagents related to contact with cats ${ }^{4219254245}$.

It was observed in the present study that pregnant women who live in rural areas have a higher and earlier risk of infection than those in urban areas, and absence of public water supply, as well as lack of garbage collection in farms are factors associated with infection ${ }^{12}$.

Compared to this study, there are few works in Brazil which evaluate multiple exposure factors for T. gondii using the presence of specific IgG anti- T. gondii antibodies. Previous studies have developed this perspective with pregnant women ${ }^{926}$ and studied ocular toxoplasmosis ${ }^{6}{ }^{19}$.

Pregnant women from rural areas were seropositive in a higher frequency than those from urban areas. This suggests that women on farms spend more time exposed to T. gondii, since they carry out activities related to farming and thus have a higher probability of coming into contact with oocysts. Contact with soil was the variable most related to toxoplasmic infection.

Intake of poorly cooked meat is related to transmission of infection in both rural and urban areas. Pregnant women who consume homemade sausage showed higher adjusted prevalence in rural areas. Aging may be more related to increase of infection probability in rural area than in urban areas.

Since cats are the only sources of oocysts, data indicate that they are the sole source for environmental contamination. The main risk factors were identified as contact with soil, housing without garbage collection, intake of poorly cooked meat, and age.

\section{ACKNOWLEDGEMENTS}

To Dr Adauto José G Araújo and Dr Karl Reinhard for reviewing the manuscript.

\section{REFERENCES}

1. Amendoeira MRR. Tentativa de Evidenciação do Toxoplasma gondii em Saliva e/ou Amígdalas em Dois Grupos de Indivíduos do Rio de Janeiro - 
Aspectos Sorológicos, MSc Thesis, Instituto Oswaldo Cruz, Fundação Oswaldo Cruz, Rio de Janeiro, RJ, 1980.

2. Amendoeira MRR. Mecanismos de transmissão da toxoplasmose. Anais da Academia Nacional de Medicina 155: 224-225, 1995.

3. Apt W, Thiermann E, Niedmann G, Pasmanik S. Toxoplasmosis, Universidad de Chile, Santiago, 1973

4. Araújo FAP. Avaliação Soroepidemiológica de Anticorpos para Toxoplasma gondii, Nicolle \& Manceaux, 1909 em Soros de Suínos ( Sus scrofa) da Região da Grande Erechim, RS, Brasil, Detectados Através das Técnicas de Imunofluorescência Indireta e Imunoenzimática, PhD Thesis, Instituto Oswaldo Cruz, Fundação Oswaldo Cruz, Rio de Janeiro, RJ, 1999.

5. Arias Ml, Reyes L, Chinchilla M, Linder E. Seroepidemiology of Toxoplasma gondii (Apicomplexa) in meat producing animals in Costa Rica. Revista de Biologia Tropical 42: 15-20, 1994.

6. Bahia-Oliveira LMG, Abreu AMW de, Azevedo-Silva J, Oréfice F. Toxoplasmosis in Southeastern Brazil: an alarming situation of highly endemic acquired and congenital infection. International Journal of Parasitology 31: 133-137, 2001.

7. Bonametti AM, Passos JN, Silva EMK, Macedo ZS. Probable transmission of acute toxoplasmosis through breast feeding. Journal of Tropical Pediatrics 43:116,1997.

8. Choi WY, Nam HW, Huh YR, Kang MW, Cho SY, DubeyJP. Foodborne outbreaks of human toxoplasmosis. Journal of Infectious Diseases 175: 1280-1282, 1997.

9. Coutinho SG, Souza WJS, Camillo-Coura L, Marzochi MCA, Amendoeira MRR. Levantamento dos resultados das reações de imunofluorescência indireta para toxoplasmose em 6.079 pacientes de ambulatório ou gestantes no Rio de Janeiro realizadas durante os anos de 1971 a 1977. Revista do Instituto de Medicina Tropical de São Paulo 23: 48-56, 1981.

10. DubeyJP, Miller NL, Frenkel JK Toxoplasma gondii life cycle in cats. Journal of the American Vetereninary Medical Association 157: 1767-1770, 1970.

11. Dubey JP, Rolor EA, Smith K, Kwok OC, Thulliez P. Low seroprevalence of Toxoplasma gondii in feral pigs from a remote island lacking cats. Journal of Parasitology 83: 839- 841, 1997.

12. Etheredge GD, Frenkel JK. Human Toxoplasma infection in Kuna and Embera children in the Bayano and San Blas, eastern Panamá. American Journal of Tropical Medicine and Hygiene 53: 448-457, 1995.

13. Feldman HA. Toxoplasmosis: an overview. Bulletin of the New York Academy of Medicine 50: 110-127, 1974

14. Ferraroni JJ, Marzochi MCA. Prevalência da infecção pelo Toxoplasma gondii em animais domésticos, silvestres e grupamentos humanos da Amazônia. Memórias do Instituto Oswaldo Cruz 75: 99-109, 1980.

15. Frenkel JK. Pathology and pathogenesis of congenital toxoplasmosis. Bulletin of the New York Academy of Medicine 50: 182-191, 1974.

16. Frenkel JK. La inmunidad en la toxoplasmosis. Boletin de la Oficina Sanitaria Panamericana 100: 283-295,1986.

17. Frenkel JK, Dubey JP. Toxoplasmosis and its prevention in cats and man. Journal of Infectious Diseases 126: 664-673, 1972.

18. Galván-Ramirez ML, Guillen-Vargas C, Saavedra-Duran R, Islos-Rodriguez A. Analysis of Toxoplasma gondii antigens with sera from toxoplasmosis patients. Revista da Sociedade Brasileira de Medicina Tropical 31: 271-277, 1998.

19. GarciaJL, Navarro IT, Ogawa L, Oliveira RC, Kobilka E. Soroprevalência, epidemiologia e avaliação ocular da toxoplasmose humana na zona rural de Jaguapitã ( Paraná), Brasil. Pan American Journal of Public Health 6: 157-163, 1999

20. González-Morales T, Bacallo-GallesteyJ, Garcia-Santana CA, Molina-Garcia JR. Prevalencia de anticuerpos anti-Toxoplasma gondii en una población de mujeres embarazadas en Cuba. Gaceta Medica de México 131: 499-503,1992.

21. Hutchison WM. Experimental transmission of Toxoplasma gondii. Nature 206: 961-962, 1965

22. Jacobs L. Toxoplasma and toxoplasmosis. Annual Review of Microbiology 17: 429-450, 1963.

23. Jacobs L. New knowledge of Toxoplasma and toxoplasmosis. Advances in Parasitology 11: 531-669, 1973.

24. Jacobs L, Melton ML. A procedure for testing meat samples for Toxoplasma with preliminary results of a survey of pork and beef samples. Journal of Parasitology 43(suppl): 38-39, 1957.
25. Jamra LMF. Contribuição para a Epidemiologia da Toxoplasmose: Inquérito em 100 Famílias de uma Área da Cidade de São Paulo, PhD Thesis, Faculdade de Medicina, Universidade de São Paulo, São Paulo, 1964.

26. Jamra LM, Santos OC, Guimarães EC. Frequency of antibodies to Toxoplasma in pregnant women and their newborn in São Paulo City, Brazil. Revista Brasileira de Pesquisas Médicas e Biológicas 12: 279-285, 1997.

27. Jeannel D, Niel G, Costagliola D, Danis M, Traore BM, Gentilini M. Epidemiology of toxoplasmosis among pregnant women in the Paris area. International Journal of Epidemiology 17: 595- 601, 1988.

28. Kahn HÁ, Sempos CT. Statistical Methods in Epidemiology, Oxford University Press, New York, 1989.

29. Kasper LH, Ware PL. Recognition of stage-specific oocyst sporozoite antigens of Toxoplasma gondii by human antisera. Journal of Clinical Investigation 75: 1570-1577, 1985.

30. Lynfield R, Hsu HW, Guerina NG. Screening methods for congenital Toxoplasma and risk of disease. Lancet 353: 1899-1900, 1999.

31. McCabe RE, Remington JS. Toxoplasmosis: the time has come. The New England Journal of Medicine 318: 313-315, 1988.

32. Melamed J. Retinocoroidite Toxoplásmica. PhD Thesis, Faculdade de Medicina, Universidade Federal de Minas Gerais, Belo Horizonte, 1991.

33. Melamed J, Raffin NN, Agnes MJ. Toxoplasmose no Rio Grande do Sul - Inquérito sorológico no interior do Estado. Revista de Patologia Tropical 10: 1-7, 1981.

34. Olusi T, Grob U, Ajayi J. High incidence of toxoplasmosis during pregnancy in Nigeria. Scandinavian Journal of Infectious Diseases 28: 645-646, 1996.

35. Osório MR, Garcia VC, Maldonado JL, Gonzalez FP. Seroepidemiologia de la toxoplamosis I - Estudio realizado em sueros humanos por la tecnica de immunofluorescência indireta. Revista Iberica de Parasitologia 37: 123-132, 1977.

36. Rawal BW. Toxoplasmosis: a dye-test survey on sera from vegetarians and meat eaters in Bombay. Transactions of the Royal Society of Tropical Medicine and Hygiene 53: 61-63, 1959

37. Rawlins SC, Prabhakar P. Toxoplasmosis in young Jamaicans. Journal Tropical Pediatrics 35: 234-236, 1989.

38. Remington JS. Toxoplamosis in the adult. Bulletin of the New York Academy of Medicine 50: 211-227, 1974

39. Rey L. Parasitologia: Parasitos e Doenças Parasitárias do Homem das Américas e da África, 2ª edição Guanabara Koogan, Rio de Janeiro, RJ, 1991.

40. Ricciardi ID. Prevalência de Reatores Humanos ao Toxoplasma gondii no Brasil. Inquérito Sorológico Piloto, PhD Thesis, Instituto de Microbiologia, Universidade Federal do Rio de Janeiro, Rio de Janeiro, 1976.

41. Sacks JJ, Roberto RR, Brooks NE. Toxoplasmosis infection associated with raw goat's milk. The Journal of the American Association 248: 1728-1732, 1982.

42. Sánchez RM, Sánchez RM, Hernández MS Carvajales AF. Aspectos seroepidemiologicos de la toxoplasmosis en 2 municipios de la provincia de Ciego de Avila: septiembre de 1989. Revista Cubana de Medicina Tropical 41: 214-225, 1989.

43. Silveira C. Retinocoroidite presumivelmente toxoplásmica em 6 irmãos não-gêmeos. Arquivos Brasileiros de Oftalmologia 50: 88-91, 1987.

44. Silveira C, Belfort Jr R, Burnier Jr M, NussemblattR. Acquired toxoplasmic infection as the cause of toxoplasmic retinochoroiditis in families. American Journal of Ophtalmology 106: 362-364, 1988.

45. Souza WJ, Coutinho SG, Lopes CW, Dos Santos CS, Neves NM, Cruz AM. Epidemiological aspects of toxoplasmosis in schoolchildren residing in localities with urban or rural characteristics within the city of Rio de Janeiro, Brazil. Memórias do Instituto Oswaldo Cruz 82: 475-482, 1987.

46. Spalding SM. Acompanhamento de Gestantes com Risco de Transmissão de Infecção Congênita por Toxoplasma gondii Nicolle \& Manceaux, 1909 na Região do Alto Uruguai, RS, Brasil - Diagnóstico e Aspectos Epidemiológicos, PhD Thesis, Instituto Oswaldo Cruz, Fundação Oswaldo Cruz, Rio de Janeiro, RJ, 2000.

47. Wallace GD. The role of the cat in the natural history of Toxoplasma gondii. American Journal of Tropical Medicine and Hygiene 22: 313-322, 1973.

48. Williams KAB, ScottJM, Macfarlane DE, Williams JM, Eliasjones TF, Willians H. Congenital toxoplasmosis: a prospective survey in the West of Scotland. The Journal of Infection 3: 219-229, 1981.

49. Wong SY, Remington JS. Toxoplasmosis in pregnancy. Clinical Infectious Diseases 18: 853-862, 1994 